\title{
A LEGAL ADVISOR'S RESPONSIBILITY TO THE INTERNATIONAL COMMUNITY: WHEN IS LEGAL ADVICE A WAR CRIME?
}

\author{
Ellia Ciammaichella*
}

\section{INTRODUCTION}

Practically every attorney in every state of the United States of America takes an oath to uphold the US and that state's Constitution. Upon taking the oath, most US lawyers become an officer of the court ("judicial officer"). As an officer of the court they are held to a higher standard of integrity and candor as is required by that state's professional responsibility rules. As such, although an attorney is an advocate for his client, in some situations, an attorney must set aside his role as advocate and assert his role as judicial officer to maintain the integrity of the judicial system and uphold the US and state Constitution.

The constant tension between an attorney's role as judicial officer and advocate occurs because giving advice about the law an attorney's main purpose and often that advice may further criminal conduct. However, as Professor Newman eloquently put it, “[n]either the status of 'lawyer' nor the obligation to provide access to the law should exempt lawyers from the criminal liabilities which face everyone else."1

While Professor Newman was specifically referring to a lawyer's responsibility in the domestic sphere, this is equally applicable to a legal advisor's responsibility to the international community. Concededly, an attorney does not take an oath to uphold international law. However, because a lawyer should not be exempt from the law, each and every attorney, like everyone else, should be legally responsible to the international community.

This article argues that there are some limited situations where a lawyer, specifically a government legal advisor, has certain basic legal responsibilities to the international community that trump his responsibility to his government. As the Nuremberg trials emphasized, no government official is immune from an international crime simply because he is acting within his official capacity. Rather, because the State cannot act without people to act on

* B S, University of California at Berkeley, 2001; JD, with honors, The George Washington University Law School, 2005; Law Clerk for the Honorable Alex R Munson. This article was written in conjunction with Professor Carnahan's Law of War class at The George Washington University Law School.

${ }^{1}$ Joel Newman Legal Advice Toward Illegal Ends, 28 U Rich L Rev 287, 288 (1994). 


\section{THE DENNING LAW JOURNAL}

its behalf and because only the person acting on behalf of the State may commit war crimes, the official is individually responsible for his actions. ${ }^{2}$

Furthermore, while a legal advisor is not truly considered a policymaker, this, by itself, does not dissociate the legal advisor from the policy. Accordingly, when a legal advisor is so entangled in the policy such that he breaches his responsibility to the international community, he must be held accountable for the criminality of that policy.

As such, this article will analyze the extent of responsibility that a government legal advisor legally owes to the international community. As background, Part II of this article surveys two affirmative defenses that generally arise when prosecuting a government official for a war crime: official immunity and immunity for acting pursuant to superior orders. Part III suggests an analysis of whether a legal advisor has breached his international responsibility should depend on a sliding scale test that considers the legal advisor's mens rea and the legal advisor's influence over the illegal policy. Part IV provides a practical application of the suggested analysis by evaluating four scenarios where a legal advisor is internationally responsible for playing a significant role in an international crime.

\section{BACKGROUND}

There are two main issues that, like any other government official, are relevant to prosecuting a legal advisor as a war criminal: (a) immunity for acts committed as a high government official; and (b) immunity for acts made pursuant to superior orders.

A legal advisor may not claim immunity for international crimes simply because he is acting in his official capacity. ${ }^{3}$ This follows from two

${ }^{2}$ United States $v$ von Leeb (US Mil Trib 1948), reprinted in 11 Trials of War Criminals Before the Nurnberg Military Tribunals Under Control Council Law No 10, at 462, 508 (1950) [hereinafter High Command Case] ("The state being but an inanimate corporate entity or concept, it cannot as such make plans, determine policies, exercise judgment, experience fear, or be restrained or deterred from action except through its animate agents and representatives").

3 The International Law Commission ("ILC") succinctly summarized this in Nuremberg Principle III: "The fact that a person who committed an act which constitutes a crime under international law acted as Head of State or responsible Government official does not relieve him from responsibility under international law.” Principles of International Law Recognized in the Charter of the Nürnberg Tribunal and in the Judgment of the Tribunal: Report of the International Law Commission to the General Assembly, 5 UN GAOR Supp (No 12) at 11, UN Doc A/1316 (1950), reprinted in [1950] 2 YB Int'l L Comm'n 364, 375, UN Doc A/CN.4/SER.A/1957/Add [hereinafter Nürnberg Principles]; see J Spiropoulos, Formulation of Nürnberg Principles, UN Doc A/CN.4/22 (1950), reprinte in [1950] 


\section{THE DENNING LAW JOURNAL}

underlying tenets: (1) international law is superior to domestic law; and (2) deterrence is greatest where individual responsibility is placed on the authors of criminal policies. Although the superiority of international law may simply support State liability, "[i]t would be an utter disregard of reality and but legal shadow-boxing to say that only the [S]tate, the inanimate entity, can have guilt, and that no guilt can be attributed to its animate agents who devise and execute its policies." ${ }^{4}$ Rather, because the State cannot act on its own and must necessarily act through the will of its agents, the only way to deter a State's criminal action is by making its agents, including legal advisors, criminally responsible for their personal acts. ${ }^{5}$

The principle of international law, which under certain circumstances, protects the representatives of a state, cannot be applied to acts which are condemned as criminal by international law. The authors of these acts cannot shelter themselves behind their official position in order to be freed from punishment in appropriate proceedings. ${ }^{6}$

Thus, while a legal advisor's official capacity shields him from most liability, the legal advisor is directly responsible for his actions that are criminal under international law. ${ }^{7}$

2 YB Int'l L Comm'n 181, 192, UN Doc A/CN.4/SER.A/1957/Add.1; see also Draft Code of Crimes Against the Peace and Security of Mankind: Report of the International Law Commission to the General Assembly, 51 UN GAOR Supp. (No 10) at 14, art 7, UN Doc. A/51/10, Corr 1, Corr 2 (1996), reprinted in [1996] 2 YB Int'l L Comm'n 15, pt 2, 31 UN Doc A/CN.4/SER.A/1996/Add.1, Corr 1 [hereinafter Draft Code of P\&SM] ("The official position of an individual who commits a crime against the peace and security of mankind, even if he acted as head of State or Government, does not relieve him of criminal responsibility or mitigate punishment.”) ${ }^{4}$ High Command Case, above note 2, at 508.

${ }^{5}$ United States v Göring (Int'l Mil Trib 1946), in 1 Trial of the Major War Criminals Before the International Military Tribunal 223 (1947), available at http://www.mazal.org/Default.htm [hereinafter Major War Criminals] ("Crimes against international law are committed by men, not by abstract entities, and only by punishing individuals who commit such crimes can the provisions of international law be enforced."); High Command Case, above note 2, at 508 ("The state being but an inanimate corporate entity or concept, it cannot as such make plans, determine policies, exercise judgment, experience fear, or be restrained or deterred from action except through its animate agents and representatives.”)

${ }_{7}^{6}$ Major War Criminals, above note 5, at 223.

7 Sir Arthur Watts gives a concise explanation of a Head of State's general protections, privileges, and immunities. Sir Arthur Watts, The Legal Position in International Law of Heads of States, Heads of Governments and Foreign Ministers, in 247 Recueil Des Cours 19, 35-81 (1994). Many of these immunities can be extended, by analogy, to other government officials. 


\section{THE DENNING LAW JOURNAL}

In addition, the mere fact that an official acts in some other capacity besides a military leader does not immunize him from international responsibility. For example, although Joachim von Ribbentrop was the Foreign Policy Adviser to Hitler, ${ }^{8}$ the International Military Tribunal ("IMT") held that even assuming that Von Ribbentrop "was personally concerned with the diplomatic rather than the military aspect of those actions, his diplomatic efforts were so closely connected with war that he could not have remained unaware of the [illegality] of Hitler's actions."9

Furthermore, a person acting in his official capacity as a legal advisor may not simply shield himself from his initiation or creation of criminal policy by claiming that his work product is legal advice. For example, Rudolf Lehmann, Chief of the Legal Department of the OKW, was sentenced to seven years imprisonment for his "criminal connection" to the Barbarossa Jurisdiction Order, the Commando Order, and the Night and Fog Decree. ${ }^{10}$ In addition, Joachim von Ribbentrop, although the Foreign Policy Adviser to Hitler, was convicted of war crimes for his memorandum justifying the Nazi's aggressive actions on Norway, Denmark, and the Low Countries. ${ }^{11}$

Concomitant with the principle that one may not claim immunity for acts within one's official capacity is that acting pursuant to superior orders does not necessarily immunize a legal advisor from international responsibility. ${ }^{12}$ If a person cannot claim immunity for his official actions, then a junior person

\footnotetext{
${ }^{8}$ Major War Criminals, above note 5, at 287.

${ }^{9}$ Id at 285.

${ }^{10}$ High Command Case, above note 2, at 690-95.

${ }^{11}$ Major War Criminals, above note 5, at 286 ("Von Ribbentrop was advised in advance of the attack on Norway and Denmark and of the attack on the Low Countries, and prepared the official Foreign Office memoranda attempting to justify these aggressive actions”); see Richard B. Bilder \& Detlev F Vagts, Speaking Law to Power: Lawyers and Torture, 98 AJIL 689, 694 (2004) ("It is worth recalling that Ribbentrop was convicted at Nuremberg for having issued memoranda justifying the Nazi preemptive strikes against Norway, Denmark, and the Low Countries in 1940").

${ }^{12}$ This is ILC Principle IV: "The fact that a person acted pursuant to order of his Government or of a superior does not free him from responsibility under international law, provided a moral choice was in fact possible to him." Nürnberg Principles, above note 3, 2 YB Int'l L Comm'n at 375; see J Spiropoulos, above note 3, 2 YB Int'l L Comm'n at 192-93; see also Draft Code of P\&SM art 5, above note 3, [1996] 2 YB Int'l L Comm'n at 23 ("The fact that an individual charged with a crime against the peace and security of mankind acted pursuant to an order of a Government or a superior does not relieve him of criminal responsibility, but may be considered in mitigation of punishment if justice so requires”).
} 


\section{THE DENNING LAW JOURNAL}

acting pursuant to superior orders may not claim immunity for obeying or for being influenced by those superior orders. ${ }^{13}$

\section{ANALYSIS}

Because a legal advisor is not exempt from international law, to the extent that a legal advisor is "[c]omplicit in the commission of . . . a war crime," he is acting criminally under international law. ${ }^{14}$ For example, under the policymaker rule, a policymaker who creates or implements a policy, order, legislation, or decree which authorizes or directs the commission of a crime is a war criminal if the crime was actually committed in the prosecution of war. ${ }^{15}$ Generally, a legal advisor does not fall under the policymaker rule. However, if a war crime actually occurred, a legal advisor maybe criminally responsible for policy that directed or implemented the war crime if he understands the consequences of the policy and has enough influence to shape the policy. In other words, a legal advisor has not committed a war crime unless he has what the International Military Tribunal called a "moral choice."

\section{THE THEORY OF COMPLICITY REQUIRES THAT A WAR CRIME ACTUALLY OCCUR}

Because a legal advisor's international responsibility is based on complicity, and not conspiracy, the threshold inquiry, of course, is whether a war crime actually occurred. ${ }^{16}$ Thus, an official is not individually responsible

${ }^{13}$ A legal advisor acting pursuant to superior orders, however, may not have the requisite culpability. Since mere association to criminal conduct is not sufficient, acting pursuant to superior orders may effectively negate an essential part of the balancing test prescribed below. High Command Case, above note 2, at 484 ("[Because] criminal responsibility is an individual matter[,] criminal guilt must be personal”).

${ }^{14}$ Nürnberg Principles, above note 3, 2 YB Int'l L Comm'n at 377.

${ }^{15}$ Draft Code of P\&SM art 5, above note 3, 2 YB Int'l LComm'n at 23; see Agreement for the Prosecution and Punishment of the Major War Criminals of the European Axis, August. 8, 1945, Appendix, art 6, 59 Stat 1544, 82 UNTS 279 [hereinafter Charter of the International Military Tribunal] ("Leaders, organizers, instigators, and accomplices participating in the formulation or execution of a common plan or conspiracy to commit any of the foregoing crimes are responsible for all acts performed by any persons in execution of such plan.”); Whitney R. Harris, Tyranny on Trial: The Evidence at Nuremberg 503 (rev. ed. 1999) ("War crimes must be committed in the course of war, and must be related to war prosecution").

${ }^{16}$ Draft Code of P\&SM art 2, above note 3, [1996] 2 YB Int'l LComm'n at 18-19; see, eg, High Command Case, above note 2, at 565 (acquitting Hugo Sperrle because, although he may have ordered subordinate units to force Russian prisoners of war to 


\section{THE DENNING LAW JOURNAL}

if an international standard was not breached ${ }^{17}$ or if the breach did not amount to a "grave harm to the international community." 18

While some international scholars have interpreted the Geneva Conventions to delineate war crime standards based on whether the armed conflict was international or non-international in character, the current customary international law makes no such distinction. During international armed conflict, that is armed conflict between two or more (Sovran) states, ${ }^{19}$ war crimes are acts that constitute a grave breach of the Geneva Conventions. ${ }^{20}$ Grave breaches of the Geneva Conventions include willful

work in construction units, there was no evidence in the record that a crime was actually committed).

${ }^{17}$ Conspiracy to commit a war crime has not yet risen to the level of international responsibility. However, because a conspiracy to commit an act of aggression is the essence of a crime against peace, conspiracy is an international crime in that context. Major War Criminals, above note 5, at 223. Some commentators, however, suggest that conspiracy, as a war crime, has gained status in the international community. See Howard S. Levie, The Statute of the International Tribunal for the Former Yugoslavia: A Comparison with the Past and a Look at the Future, 21 Syracuse J Int'l L\& Com 1, 11 n 60 (1995). However, conspiracy has not risen to the level of customary international law. Professor Little and Richard Barrett succinctly explained the difference between complicity and conspiracy in Lessons of Yugoslav Rape Trials: A Role for Conspiracy Law in International Tribunals, 88 Minn L Rev 30, 37 (2003).

${ }^{18}$ Robert K Woetzel, Nuremberg Trials in International Law 110 (2d ed. 1962); see United States $v$ List (US Mil Trib1948), reprinted in 11 Trials of War Criminals Before the Nuernberg Military Tribunals Under Control Council Law No 10, at 1241 (1950) [hereinafter Hostage Case] ("An international crime is such an act universally recognized as criminal, which is considered a grave matter of international concern and for some valid reason cannot be left within the exclusive jurisdiction of the state that would have control over it under ordinary circumstances").

${ }^{19}$ The definition of international armed conflict is based on Common Article 2. Geneva Convention for the Amelioration of the Condition of the Wounded and Sick in Armed Forces in the Field, August 12, 1949, art 2, 6 UST 3114, 75 UNTS 31 [hereinafter Geneva Convention I]; Geneva Convention for the Amelioration of the Condition of Wounded, Sick and Shipwrecked Members of the Armed Forces at Sea, August 12, 1949, art 2, 6 UST 3217, 75 UNTS 85 [hereinafter Geneva Convention II]; Geneva Convention Relative to the Treatment of Prisoners of War, August. 12, 1949, art 2, 6 UST 3316, 75 UNTS 135 [hereinafter Geneva Convention III]; Geneva Convention Relative to the Protection of Civilian Person in Time of War, August. 12, 1949, art 2, 6 UST 3516, 75 UNTS 287 [hereinafter Geneva Convention IV].

${ }^{20}$ Oren Gross, The Grave Breaches System and the Armed Conflict in the Former Yugoslavia, 16 Mich J Int'l L783, 800 n 58 (1995); see Geneva Convention I, above note 19, art 49; Geneva Convention II, above note 19, art 50; Geneva Convention III, above note 19, art 129; Geneva Convention IV, above note 19, art 146; Protocol Additional to the Geneva Conventions of 12 August 1949, and Relating to the 


\section{THE DENNING LAW JOURNAL}

killing, torture or inhuman treatment, and willfully causing great suffering or serious injury to body or health. ${ }^{21}$

Concededly, when the conflict is not of an international character, the Geneva Conventions do not explicitly mandate individual responsibility. Common Article 3, however, creates limited protection to persons participating in a non-international armed conflict. ${ }^{22}$ "Guerrillas, therefore, even if unprivileged combatants and not entitled on capture to the status of prisoners of war, would appear now always to be entitled to humane treatment and trial by a regular court." ${ }^{23}$ Moreover, the International Court of Justice ("ICJ") stated that Common Article 3 is the "minimum yardstick" for any type of armed conflict and constitutes customary international law. ${ }^{24}$ Like grave breaches of the Geneva Conventions, violence to life and person, in particular murder of all kinds, mutilation, cruel treatment and torture[,] . . .taking of hostages[,] . . .outrages upon personal dignity, in particular humiliating and degrading treatment[,] . . . the passing of sentences and the carrying out of executions without previous [judgment] pronounced by a regularly constituted court, affording all the judicial guarantees which are recognized as indispensable by civilized peoples ${ }^{25}$ are all concerns that the international community does not take lightly. Accordingly, if the IMT's analysis is similarly applicable to non-international armed conflict, government officials are internationally responsible for violating Common Article 3 or, in the alternative, responsible for violating customary international law. ${ }^{26}$

Protection of Victims of International Armed Conflicts, June 8, 1977, art 85 1, 1125 UNTS. 3 [hereinafter Geneva Protocol I].

${ }^{21}$ Geneva Convention I, above note 19, art 50; Geneva Convention II, above note 19, art 51; Geneva Convention III, above note 19, art 130; Geneva Convention IV, above note 19 , art 147.

${ }^{22}$ Geneva Convention I-V, above note 19, art 3 [collectively Common Article 3].

23 Julius Stone Legal Controls of International Conflict 567 (2d ed 1959).

${ }^{24}$ Military and Paramilitary Activities (Nicar v US), 1986 ICJ 14218 (June 27).

${ }^{25}$ Common Article 3, above note 22.

${ }^{26}$ Id Geneva Protocol II also deals with the rules of non-international armed conflict. See Protocol Additional to the Geneva Conventions of 12 August 1949, and Relating to the Protection of Victims of Non-International Armed Conflicts, June 8, 1977, 1125 UNTS. 609 [hereinafter Geneva Protocol II]. 


\section{SUFFICIENT CULPABILITY OR “MORAL CHOICE” IS A REQUISITE FOR INTERNATIONAL CRIMINALITY}

Even if a war crime actually occurred, a legal advisor will not be internationally responsible for illegal acts unless he has sufficient culpability. ${ }^{27}$ The Nuremberg Military Tribunal ("NMT") in the High Command Case explained that the culpability requirement was extracted from "fundamental principle[s] of criminal law as generally accepted by the civilized nations of the world . ..." Id. Similarly, the IMT defined culpability by asking whether the actor had a "moral choice." 28 The IMT determined whether the actor had a "moral choice" by analyzing the actor's mens rea and his actual ability to influence policy on the other. ${ }^{29}$

Accordingly, when a legal advisor has a high mens rea and a weak ability to influence or ignore criminal policy, he is sufficiently culpable. For example, this occurs when a legal advisor has actual knowledge of the criminality of the policy. ${ }^{30}$ Actual knowledge ${ }^{31}$ satisfies the "moral choice" standard because the legal advisor knows that one choice is permissible and

${ }^{27}$ High Command Case, above note 2, at 484. The Nuremberg Military Tribunal ("NMT") in the High Command Case noted that the culpability requirement was extracted from "fundamental principle[s] of criminal law as generally accepted by the civilized nations of the world . ..." Id at 510. Thus, since mere association is not sufficient to support criminal responsibility, strict liability does not satisfy the culpability standard. Id at 511 ("[A person] cannot be held criminally responsible for a mere error in judgment as to disputable legal questions").

${ }^{28}$ The International Military Tribunal ("IMT") acknowledged that the requisite individual culpability is satisfied when a "moral choice was in fact possible." Major War Criminals, above note 5, at 224. The NMT described the requisite culpability as "a personal act voluntarily done with knowledge of its inherent criminality under international law." High Command Case, above note 2, at 511.

${ }^{29}$ In essence, the mens rea analysis tests whether the actor understood that he had a decision to make and the ability to influence policy tests whether the actor had the ability to choose between right and wrong.

${ }^{30}$ High Command Case, above note 2, at 693. For example, in holding Lehmann responsible for the criminality of the Commando Order, the NMT emphasized that "[Lehmann] was well aware of the criminal nature of this order." Id at 693.

31 The Model Penal Code ("MPC") defines knowledge in two ways: “(i) if the element involves the nature of his conduct or the attendant circumstances, he is aware that his conduct is of that nature or that such circumstances exist, and (ii) if the element involves a result of his conduct, he is aware that it is practically certain that his conduct will cause such a result.” Model Penal Code § 2.02(2)(b) (1962). "When knowledge of the existence of a particular fact is an element of an offense, such knowledge is established if a person is aware of a high probability of its existence, unless he actually believes that it does not exist.” Id at 2.02(8). 


\section{THE DENNING LAW JOURNAL}

the other choice is illegal. Thus, the legal advisor has the chance to choose the permissible action.

On the other end of the spectrum, if a legal advisor has a low mens rea but a strong ability to influence criminal policy he is criminally culpable. The axiom that ignorance of the law is no excuse speaks well for this type of situation. ${ }^{32}$ At this level of mens rea, criminal responsibility would apply "if a [legal advisor] can reasonable be expected to know that the act is a crime."33 Thus, the standard is whether a reasonable legal advisor should have known that the policy was criminal. ${ }^{34}$

In this respect, the author argues that the reasonable legal advisor standard is the general practice of legal advisors as recognized by civilized nations. ${ }^{35}$ One can appreciate this by analyzing the High Command Case and comparing the reasonable legal advisor with the field commander of normal intelligence ("reasonable field commander") and the differing roles that they play in war. The NMT in the High Command Case reasoned that because the field commander performs in active combat and does not have the full resources that are available to legal advisors, a reasonable field commander "has the right to presume, in the absence of specific knowledge to the contrary, that the legality of such orders has been properly determined before their issuance.”36 Thus, the NMT found it was excusable for a field commander to transmit criminal orders during active combat when he passed the order down the

\footnotetext{
${ }^{32}$ Woetzel, above note 18 , at 118 -19 ("It is clear the ignorance of the criminal nature of the act is no excuse .. ").

${ }^{33} \mathrm{Id}$ at 119 . This sounds very similar to the MPC definition of negligence. See Model Penal Code 2.02(2)(d).
}

A person acts negligently with respect to a material element of an offense when he should be aware of a substantial and unjustifiable risk that the material element exists or will result from his conduct. The risk must be of such a nature and degree that the actor's failure to perceive it, considering the nature and purpose of his conduct and the circumstances known to him, involves a gross deviation from the standard of care that a reasonable person would observe in the actor's situation.

${ }^{34}$ High Command Case, above note 2, at 512 (standard of "normal intelligence"). While the NMT is referring to the standard applicable to a commanding officer, the main tenets of the NMT's analysis are equally applicable to a legal advisor. Especially important to note is that the NMT specifically distinguishes the limited legal capacities of field commanders in active combat from those of legal advisors. Id at 511. Thus, this suggests that the standard as to whether an order is "criminal upon its face" depends on the ordinary legal facilities associated with a person acting within a specific duty and in the case of a legal advisor, the ordinary legal facilities are greater than a field commander.

${ }^{35}$ The author adapts article 38 of the ICJ statute to a legal advisor's work product standard. See UN Charter annex art 38 [hereinafter Statute of the ICJ].

${ }^{36}$ High Command Case, above note 2, at 511. 


\section{THE DENNING LAW JOURNAL}

chain of command unless the order was "criminal upon its face" or if he actually knew the order was criminal. ${ }^{37}$ The NMT explained that an order is "criminal upon its face" if a legal opinion was not necessary to understand the illegality of the order. ${ }^{38}$

However, compared to a field commander, a legal advisor is in a better position to influence policy: a reasonable legal advisor is not generally in active combat and has the faculties to better understand the legality of the policy. Thus, the legal advisor may be culpable when he does not actually know that the policy is "criminal upon its face." On the other hand, if, after diligent research, a legal advisor cannot determine whether an act is criminal, then he would be in a situation similar to a reasonable field commander: he would not have the ability to choose between right and wrong.

Finally, if he had absolutely no ability to influence criminal policy(,) then no matter what his mens rea was, he had no "moral choice" and is not internationally responsible for the war crimes that occurred due to the criminal policy under the policymaker rule. ${ }^{39}$ A "moral choice" is lacking in two circumstances: (1) where the actor has no ability to influence the policy; ${ }^{40}$ and (2) where a reasonable person could not have acted any other way. ${ }^{41}$

An actor falls under the first circumstance only if he did all that he could and yet failed to resist the illegal policy. While Professor Woetzel suggests that a tribunal may consider the "extent an individual could resist an illegal order," ${ }^{42}$ implying that something short of doing everything to resist the illegal policy would suffice, the Justice Case suggests otherwise. Most telling is that in the Justice Case, Curt Rothenberger, the State Secretary of the Reich Ministry of Justice, was convicted of "aid[ing] and abett[ing] in the program of racial persecution, and notwithstanding his many protestations to the

\footnotetext{
${ }^{37}$ Id at 509; $c f$ Hostage Case, above note 18, at 1236 ("[I]f the illegality of the order was not known to the inferior, and he could not reasonably have been expected to know of its illegality, no wrongful intent necessary to the commission of a crime exists and the inferior will be protected"). This "clearly criminal" or criminality "on its face” standard suggests a recklessness standard. See Model Penal Code 2.02(2)(c) (1962).

${ }^{38}$ High Command Case, above note 2, at 512.

${ }^{39}$ Some tribunals seem to refer to this as an affirmative defense.

${ }^{40}$ In the circumstance where the actor has no ability to influence the policy, it is unclear whether the burden of proof is on the prosecution or the defense.

${ }^{41}$ This is a claim of duress. According to the final judgment in Prosecutor $v$. Erdemovic, "duress does not afford a complete defence to a soldier charged with a crime against humanity and/or a war crime involving the killing of innocent human beings...." Prosecutor v. Erdemovic, No IT-96-22-A, Appeals Chamber Judgment 17 (October 7, 1997), available at http://www.un.org/icty.

${ }^{42}$ See Woetzel, above note 18, at 118-19.
} 


\section{THE DENNING LAW JOURNAL}

contrary [the NMT held that] he materially contributed toward the prostitution of the Ministry of Justice." 43

However, where an actor "protests" against the application of the policy "opposes it in every way short of open and defiant refusal to obey it" and yet the policy is applied, the actor is not criminally responsible for the resulting illegal actions connected to the policy. ${ }^{44}$ A good example of an actor who fell into this circumstance is von Leeb and his connection to the Commissar Order. ${ }^{45}$ The NMT held that von Leeb did all that he could do and therefore, was not responsible for the resulting catastrophe of the Commissar Order. ${ }^{46}$

An actor is in the second circumstance if a "reasonable man would apprehend such imminent physical peril as to deprive him of freedom to choose the right and refrain from the wrong[.]" 47 In such circumstance, the actor is not personally responsible for the crime committed. According to the NMT in the Einstazgruppen Case, the reasonable man would weigh the harm caused by obeying the illegal policy against harm caused by disobeying the illegal policy. ${ }^{48}$

Arguably, as Judge Cassese stated in his separate and dissenting opinion in Prosecutor v. Erdemovic, this balance sounds like one simply must take the "lesser of two evils." 49 However, tribunal decisions have required the illegal policy to be more than the lesser of two evils. For example, in the Justice Case, even though "[t]he evidence conclusively show[ed that in order to maintain the Ministry of Justice in the good graces of Hitler and to prevent its utter defeat by Himmler's police," Franz Schlegelberger, Acting Reich Minister of Justice, was convicted under counts two and three of the indictment. $^{50}$

${ }^{43}$ United States $v$ Altstötter, (US Mil Trib1 948), reprinted in 3 Trials of War Criminals Before the Nuernberg Military Tribunals Under Control Council Law No 10, at 1118 [hereinafter Justice Case].

${ }^{44}$ High Command Case, above note 2, at 557.

${ }^{45} \mathrm{Id}$ at $555-58$.

${ }^{46}$ Id at 557-58.

${ }^{47} \mathrm{Id}$ at 509.

${ }^{48}$ United States $v$ Ohlendorf (US Mil Trib1 949), reprinted in 4 Trials of War Criminals Before the Nuernberg Military Tribunals Under Control Council Law No 10, at 471 [hereinafter Einsatzgruppen Case] ("If the nature of the ordered act is manifestly beyond the scope of the superior's authority, the subordinate may not plead ignorance of the criminality of the order. If one claims duress in the execution of an illegal order it must be shown that the harm caused by obeying the illegal order is not disproportionately greater than the harm which would result from not obeying the illegal order").

${ }^{49}$ Prosecutor v Erdemovic, No IT-96-22-A, Separate and Dissenting Opinion of Judge Cassese, 16 (October 7, 1996), available at http://www.un.org/icty.

${ }^{50}$ Justice Case, above note 43, at 1086-87. 


\section{THE DENNING LAW JOURNAL}

For several reasons, this is an onerous standard to meet. One, past cases suggest that the tribunals will assume that a person has some type of influence, in effect shifting the burden of proof onto the accused. ${ }^{51}$ Two, because the standard does not consider the actor's subjective view, the tribunal may disregard the irrationality that the actor may face when attempting to reason whether the physical peril was imminent. ${ }^{52}$

Three, the reasoning that an actor must accomplish before making a decision is hardly practical. First, the legal advisor must assess the imminence of the physical peril. ${ }^{53}$ Second, the legal advisor must evaluate the extent of damage the illegal order would cause. Third, the legal advisor must compare the competing factors and then make a decision. Fourth, this entire analysis must be based on foresight, rather than a tribunal's hindsight analysis. This onerous task would put anyone in a difficult position, but the NMT has said that being in a "difficult position" is not enough! ${ }^{54}$

Finally, even if an actor in the second circumstance understood the extent of harm, this balance must greatly favor obeying the illegal policy. The NMT stated: "the harm caused by obeying the illegal [policy] is not disproportionately greater than the harm which would result from not obeying the illegal [policy]." 55 Thus, unless the choice is to kill or be killed, the balance does not seem to greatly favor obeying the illegal policy. ${ }^{56}$

Accordingly, while an affirmative defense exists on paper, it rarely meets reality. ${ }^{57}$

\section{HYPOTHETICAL SCENARIOS}

Concededly, there are many circumstances where legal advice is too tangential to the creation or the implementation of the criminal policy for the legal advisor to meet the requisite culpability for international criminal

\footnotetext{
${ }^{51}$ High Command Case, above note 2, at 509 (emphasizing that this is a defense of coercion or necessity). Thus, the author considers this an affirmative defense. ${ }^{52} \mathrm{Id}$

53 Id ("The defendants in this case who received obviously criminal orders were placed in a difficult position, but servile compliance with orders clearly criminal for fear of some disadvantage or punishment not immediately threatened cannot be recognized as a defense”).

${ }^{54} \mathrm{Id}$

${ }^{55}$ Einsatzgruppen Case, above note 48, at 471.

${ }^{56}$ Prosecutor v Erdemovic, No IT-96-22-Tbis, Trial Chamber II Judgment, 17 (March 5, 1998), available at http://www.un.org/icty.

${ }^{57}$ While it may seem difficult to fathom a legal advisor finding himself in "imminent physical peril,” judges and prosecutors may find themselves in this situation. See, eg, Id at 954.
} 


\section{THE DENNING LAW JOURNAL}

responsibility. However, there are several situations where the legal advisor acts under the guise of counsel but actually enters the realm of establishing or implementing policy.

In this respect, this article proposes that a high-ranking legal advisor may be internationally responsible for his "advice" under two alternative theories. The first theory, addressed in Scenario One through Three, is direct responsibility based on the legal advisor's furtherance of a criminal endeavor. This theory applies when a legal advisor gives advice knowing that it will be used for an international criminal purpose or knowing that it will be used to formulate an illegal policy. This is similar to standards established in the Model Rules of Professional Conduct as set out by the American Bar Association and is based on customary international law that planning, instigating, ordering, committing, aiding, abetting, or pursuing a common international criminal purpose is a war crime. ${ }^{58}$

The second theory, addressed in Scenario Four, is command responsibility. Unlike the first theory, this theory does not require the advice to be criminal. Instead it is based on the idea that the legal advice created a "permissive climate" for illegal conduct. ${ }^{59}$

Scenario One: A Legal Advisor Incorporates His Own Criminal Idea into the Final Version of the Policy

The simplest instance is Scenario One where a legal advisor incorporates his criminal idea into the final version of the policy. ${ }^{60}$ In this situation, the legal advisor is not even acting as a counselor. To the extent that the legal advisor claims that he is simply giving legal advice, the "legal advice" is merely a façade to hide his attempt to make criminal policy.

For example, the Nuremberg Military Tribunal ("NMT") found that Rudolf Lehmann's criminal idea, to punish individuals that would have been

${ }^{58}$ Prosecutor $v$ Tadic, No IT-94-1-T, Trial Chamber II Opinion and Judgment 249, 674 (May 7, 1997).

${ }^{59}$ Bilder \& Vagts, above note 11 , at 691.

60 Several legal advisors at the annual Legal Adviser's Meeting "stressed that the [legal advisor's] function was also part of the policy formulation process." Hans Corell, Third Legal Adviser's Meeting at UN Headquarters in New York, 87 A.J.I.L. 323, 325 (1993) [hereinafter Corell, Third Legal Adviser's Meeting]. Thus, the author suspects that legal advisors may, more often than not, encounter Scenario One. The informal meeting, organized by the "Legal Advisers of the Ministries of Foreign Affairs of Canada, India, Mexico, Poland, and Sweden, and with the assistance of the Legal Counsel of the United Nations[,]” is meant to create an atmosphere where legal advisors can spontaneously debate over the developing issues in international law. Hans Corell, Legal Advisers Meet at UN Headquarters in New York, 85 AJIL 371, 371-73 (1991) [hereinafter Corell, First Legal Adviser's Meeting]. 


\section{THE DENNING LAW JOURNAL}

acquitted by the judicial process, was integrated into the final version of the Barbarossa Jurisdiction Order. ${ }^{61}$ Finding that Lehmann was the originator of the idea, the NMT held "[Lehmann] responsible for [his] criminal connection with, participation in, and formulation of [the Barbarossa Jurisdiction Order]." ${ }^{\text {"2 }}$ In addition the NMT also held Lehmann criminally liable for his contribution in enlarging the scope of the original Terror and Sabotage Decrees. ${ }^{63}$

Thus, where the legal advisor is the originator of the criminal idea and that criminal idea becomes part of the final policy, the legal advisor is responsible for the resulting criminal policy.

\section{Scenario Two: A Legal Advisor Compiles Other People's Criminal Ideas and} is the Main Factor in Determining the Final Version of the Policy

A legal advisor in Scenario Two compiles other people's criminal ideas into one concise criminal policy. ${ }^{64}$ "If the basic idea is criminal under international law, the staff officer who puts that idea into the form of a military order, either himself or through subordinates under him, or takes personal action to see that it is properly distributed to those units where it becomes effective, commits a criminal act under international law." ${ }^{65}$ A good example of a legal advisor in Scenario Two is Lehmann and his connection to the Barbarossa Jurisdiction Order, the Commando Order, the Night and Fog Decree, and the Terror and Sabotage Decree. ${ }^{66}$

\footnotetext{
${ }^{61}$ See High Command Case, above note 2, at 691-93. The Tribunal found that it was Lehmann's idea to completely deny jurisdiction to the courts, in effect giving the troops complete discretion to dispose cases. Id at 692-93. This "left the door wide open to the decision of an officer of at least the rank of a battalion commander to impose such collective punishments as he saw fit.” Id at 692. Lehmann's idea was particularly important because, in Lehmann's own words, “troops will get rid of just those cases which they consider awkward, namely, the doubtful cases by handling them over to the courts." Id at 692-93. Thus, Lehmann intended to permit the punishment of individuals that would have been acquitted for lack of evidence. Id at 693. This, the IMT held, was criminal: "This provision in the order . . . is one of the most vicious parts of the orders." Id

${ }^{62}$ Id at 693; see Id ("This provision in the order [was] obviously [] not derived from Hitler, or Keitel, or Jodi ...”).

${ }^{63}$ Id at 695.

${ }^{64}$ The NMT described it this way: "[t]he basic criminal offense is in the essential part a staff officer [or legal advisor] performs in making effective the criminal whole.” Id at 693.

${ }^{65}$ Id at 513.

${ }^{66}$ High Command Case, above note 2, at 691-95. Although Lehmann's ideas were incorporated into the Barbarossa Jurisdiction order, the NMT emphasized that
} 


\section{THE DENNING LAW JOURNAL}

A legal advisor's responsibility in Scenario Two is based on both a deterrence and culpability rationale. The deterrence theory is based on the fact that no matter how much authority one person has, he cannot implement that policy by himself. ${ }^{67}$ Those who draft policy are "indispensable" and an "essential contribution to the final execution" of criminal policy. ${ }^{68}$ Thus, a person with a criminal idea necessarily needs other people to help implement it by consolidating it into a coherent policy. By deterring those key players, the originator of the criminal idea will be greatly impeded from implementing the criminal idea.

In addition, a legal advisor in Scenario Two meets the requisite culpability because underlying Scenario Two are two important features: (1) that a legal advisor acting in this capacity has the obligation and resources to detect the criminality of the ideas; and (2) that a legal advisor acting in this capacity has substantial influence over the final structure of the criminal policy. First, unlike the intermediate administrative officer who routinely transmits orders and has no time to screen the orders he transmits, a reasonable legal advisor has time to deliberate over the policies. ${ }^{69}$ Furthermore, unlike field commanders, a reasonable legal advisor has time and resources to detect the illegality. ${ }^{70}$ In fact, a legal advisor's specialty is to determine the legality of a proposed conduct.

Second, unlike both the intermediate administrative officer and the field commander, a legal advisor in Scenario Two has substantial influence over the final structure of the criminal policy. Because the legal advisor performs a "fundamental and essential function . . . in producing military orders [and policy] from an original idea[,]"71 a legal advisor is the "main factor in

Lehmann was also responsible for his contribution to the final form of that order. Id at 693.

${ }^{67}$ The NMT recognized this in its analysis of crimes against peace. Id at 486 ("No matter how absolute his authority, Hitler alone could not formulate a policy of aggressive war and alone implement that policy by preparing, planning, and waging such war").

${ }^{68} \mathrm{Id}$ at 515.

69 See Id at 510 (explaining that the intermediate administrative function of transmitting an order does not amount to the requisite personal guilt because "transmittal is a routine function[,]" "in many instances [it] would be handled . . . without being called to his attention[,]" and the person transmitting "is not in a position to screen orders so transmitted").

${ }^{70}$ See below Part IVB. Cf. High Command Case, above note 2, at 511 (explaining that because a field commander makes decisions in active combat and has limited legal facilities, "[a field commander] has the right to presume, in the absence of specific knowledge to the contrary, that the legality of such orders has been properly determined before their issuance").

${ }^{71}$ High Command Case, above note 2, at 691. 


\section{THE DENNING LAW JOURNAL}

[implementing] the final form" of the policy. ${ }^{72}$ A legal advisor acting in this capacity "modifie[s] those ideas within his own sphere up to a certain point and place[s] the whole into an effective military order which [is] transmitted to the troops and carried out."73 Therefore, a legal advisor acting in this capacity has the requisite culpability to be held accountable for the criminal policy.

\section{Scenario Three: A Legal Advisor Attempts to Cover A Criminal Policy with the Spin of Legality}

In Scenario Three, a legal advisor is criminally implicated where he is aware of the criminal nature of the policy, but nevertheless, attempts to give it an appearance of legality. ${ }^{74}$ Scenario Three has at least two variants. In the first variant, a legal advisor, knowing that the policy is criminal, revises the criminal policy to give it an impression of legality. ${ }^{75}$ This is especially significant in modern international law because legal advice is often an attempt to cover illegal policy with legal analysis. ${ }^{76}$ For example, Rudolf Lehmann was held criminally responsible for a part of the Commando Order for "ma[king] certain suggestions as to methods which might, by a strained construction, give some appearance of legality and be suitable for publication; constructions which he apparently did not believe himself."77

In the second variant, a legal advisor, knowing that the policy is criminal, justifies the legality of the criminal policy in hopes of convincing other people that the criminal policy is actually legal. ${ }^{78}$ It would seem that such an analysis

${ }^{72}$ Id at 693. As of 1939, customary international law made it criminal for the participation of military officers at the policy influencing level. Id at 489.

${ }_{73}^{73} \mathrm{Id}$

${ }^{74}$ Id at 693-94.

${ }^{75}$ See Id

${ }^{76}$ Newman, above note 1, at 287; see Stanko Nick, The Role of the Legal Adviser in Modern Diplomatic Services, in Modern Diplomacy (Jovan Kurbalija ed., 1998), at http://www.diplomacy.edu/Books/mdiplomacy_book/ (last visited April 14, 2005) ("It is significant that even countries and their leaders who bluntly break fundamental rules and principles of international law almost invariably make a considerable effort to wrap their acts in a legally presentable or at least justifiable form”).

${ }^{77}$ High Command Case, above note 2, at 693-94.

${ }^{78}$ See Major War Criminals, above note 5, at 286. Often in a situation like this a legal advisor is attempting to "assist or provide a 'road map'," which amounts to complicity in the criminal conduct. Bilder \& Vagts, above note 11, at 694 (citations omitted). Because legal advisors often encounter this situation, the International Law Commission has expressed doubt over the value of a legal advisor's opinion as evidence of customary international law. See Manley O. Hudson, Article 24 of the Statute of the International Law Commission, UN Doc A/CN.4/16, reprinted in 


\section{THE DENNING LAW JOURNAL}

could never amount to a war crime. After all, it is the client who chooses to act. However, legal advice is often requested to further a criminal endeavor. ${ }^{79}$ In some situations, a reasonable legal advisor would understand that the most likely reason a client would request advice on the specific issue is to avoid the consequences of a crime already committed or a crime that may be committed in the future ${ }^{80}$ For example, Ribbentrop was held criminally responsible for justifying aggressive actions on Norway, Denmark, and the Low Countries. ${ }^{81}$

Unlike the previous two scenarios, however, a legal advisor in Scenario Three may not have the requisite culpability. ${ }^{82}$ First, because the legal advisor is reviewing someone else's final product, he has less influence over the resulting policy. Second, the conduct of either revising a policy to conform to international standards or justifying the legality of the policy falls under genuine legal counsel. Thus, a more demanding mens rea standard is required to prevent the presumption of criminal responsibility based on mere association to the criminal policy.

Third, the most important reason for a higher mens rea standard is that the conduct alone may merely be a result of negligence or mistake. Before a legal advisor counsels his client on the legal consequences of a proposed conduct, the legal advisor must determine what the law is at that time and then determine whether the proposed conduct may violate the law. ${ }^{83}$ When the issue touches upon public international law, the legal advisor must not only interpret applicable treaties, but must also recognize "international custom, as

[1950] 2 YB Int'l LComm'n 24, 30, UN Doc A/CN.4/SER.A/1957/Add ("Reserve may be needed in assessing the value of [opinions of legal advisers] as evidence of customary international law, for the efforts of legal advisers are necessarily directed to the implementation of policy").

${ }^{79}$ Newman, above note 1, at 287.

${ }^{80}$ Id ("There might be legitimate reasons for such a request, but the most likely reason would be a desire to avoid prosecution for a committed crime").

${ }^{81}$ See Major War Criminals, above note 5, at 286 ("Von Ribbentrop was advised in advance of the attack on Norway and Denmark and of the attack on the Low Countries, and prepared the official Foreign Office memoranda attempting to justify these aggressive actions.”); see Bilder \& Vagts, above note 11, at 694 (analogizing Ribbentrop's issuance of the memoranda justifying the attack to a legal advisor's criminal actions).

${ }^{82}$ As stated in Part IV, above, culpability is a function of both the legal advisor's actual ability to influence policy and the legal advisor's mens rea.

${ }^{83}$ This is similar to the two-part test that Judge Anderson expressed in his concurring opinion in the Krupp Case. United States v Krupp (US Mil Trib1949), reprinted in 9 Trials of War Criminals Before the Nuernberg Military Tribunals Under Control Council Law No 10, at 405 (1950) [hereinafter Krupp Case] (“(a) [W] hat was the law at the time in question and (b) does the evidence show prima facie that the defendants or any of them violated it”). 


\section{THE DENNING LAW JOURNAL}

evidence of a general practice accepted as law, the general principles of law recognized by civilized nations, ... . [and] judicial decisions and the teachings of the most highly qualified publicists of the various nations . . ."84 Thus, because "[the] law is not static, but by continual adaptation follows the needs of a changing world[,]" 85 it is especially difficult for a legal advisor to determine the current understanding of issues not yet solidified by international consensus.

In this respect, knowledge that the policy is actually criminal would suffice. In addition, if the policy were criminal on its face, a legal advisor would have sufficient culpability to be held responsible for the policy. ${ }^{86}$

There are three practical reasons for applying criminality for Scenario Three. One, a person knowledgeable in the law is the best person to hide the criminality of the policy, thus making the crime more difficult to detect. Two, "there may be strong pressures on government lawyers [or legal advisors] to 'bend' or ignore the law in order to support policy decisions . . .." ${ }^{\text {,7 }}$ If the legal advisor is not held responsible for his advice, then he will not be deterred from caving into these strong pressures, even when his legal insight strongly suggests that the policy is criminal. Three, because "foreign policy decisions are often highly political, and policymakers and others who influence policy are often skeptical concerning the relevance of international law[,]" 88 a legal advisor who informs the government that the proposed conduct is most likely illegal will have strong influence on the final policy decision. This is especially so when the legal advisor is counseling a democratic, law-abiding country. ${ }^{89}$

\footnotetext{
${ }^{84}$ Statute of the ICJ art 38, above note 35; see Major War Criminals, above note 5, at 221.

${ }^{85}$ Major War Criminals, above note 5, at 221.

${ }^{86}$ High Command Case, above note 2, at 509. The NMT also suggested that believing the policy to be criminal is sufficient. Id at 693-94. However, if this is the case, how much faith must a legal advisor have in the legality of a policy before he is willing to venture into revising or justifying a policy? The author suggests that the NMT merely interchanged the meaning of "belief" with "knowledge." Otherwise, this would rely too heavily on the reasonable legal advisor standard, which is quite malleable.

${ }^{87}$ Bilder \& Vagts, above note 11, at 693 (citations omitted); see C G Weeramantry, Universalising International Law 212 (2004) (“All too often at the highest levels of government and foreign and military policy there is an expectation that legal opinions will conform to the wishes of those in authority ... ”).

${ }^{88}$ Bilder \& Vagts, above note 11, at 693 (citations omitted).

${ }^{89}$ More and more states have a policy of abiding by international law. Weeramantry, above note 87, at 211 ("Signs are discernible at the highest levels of state policy of an increased readiness to abide by the dictates of international law”).
} 


\section{THE DENNING LAW JOURNAL}

Scenario Four: A Legal Advisor Creates or Implements a Policy, Which While Not Illegal, Creates A Permissive Atmosphere For Criminal Conduct

Unlike the previous three instances where the legal advisor is held responsible for his direct participation in a criminal conduct, in Scenario Four, the legal advisor, if at all, is held criminally accountable based on the rubric of command responsibility. ${ }^{90}$ The best example of Scenario Four is Field Marshall Wilhelm von Leeb's connection to the Barbarossa Jurisdiction Order in the High Command Case. ${ }^{91}$ As commander of his army group, he put the Barbarossa Jurisdiction Order into the chain of command. ${ }^{92}$ The NMT concluded that even if the order was not criminal, it "was at best ambiguous in respect to the authority conferred upon a junior officer to shoot individuals who were merely suspected of certain acts." ${ }^{93}$ Furthermore, the NMT found that von Leeb did not prevent the illegal application of the order by clarification or otherwise by including further instructions. ${ }^{94}$ "Having set this instrument in motion, he must assume a measure of responsibility for its illegal application[,]" and is thus, indirectly responsible for failing to place safeguards within the order. ${ }^{95}$

The theory behind command responsibility is twofold. First, "[b]y doing nothing he cannot wash his hands of international responsibility." advisor has the ability to influence the application of the policy, and probably understands that he has this capability. Thus, when a reasonable legal advisor has reason to know that although the policy is legal, it is ambiguous, he is just as culpable as a person who implements the illegal policy. Second, in implementing an ambiguous policy, the legal advisor has breached his duty. ${ }^{97}$ Because the machinery of the government not only requires the forging and implementation of policy but also the application of that policy by others, a

\footnotetext{
${ }^{90}$ Art 5 of the Draft Code of Crimes Against the Peace and Security of Mankind succinctly summarizes command responsibility. "An individual shall be responsible for a [war crime] if that individual... [f] ails to prevent or repress the commission of such a crime in the circumstances set out in article 5...." Draft Code of P\&SM art 2, above note 3, [1996] 2 YB Int'l LComm'n at 18-19.

${ }^{91}$ High Command Case, above note 2, at 521-25.

${ }^{92}$ Id at 560.

${ }^{93}$ Id For more information about the Barbarossa Jurisdiction Order, see above note 61 and accompanying text.

${ }^{94}$ High Command Case, above note 2, at 560.

${ }^{95}$ Id at 561-62.

${ }^{96}$ Id at 512.

${ }^{97}$ See Colonel William G Eckhardt, Command Criminal Responsibility: A Plea for a Workable Standard, 97 Mil L Rev 1, 5 (1982) (emphasizing that command responsibility does not attach unless the actor has breached a duty).
} 


\section{THE DENNING LAW JOURNAL}

reasonable legal advisor should know that policy is created so that others will follow that policy. Thus, the person in charge of implementing that policy has the duty to create a policy that is sufficiently definite.

Therefore, the doctrine of command responsibility requires that a person, such as a legal advisor, who "knew or had reason to know, in the circumstances at the time, that the subordinate was committing or was going to commit such a crime[, the legal advisor must] take all necessary measures within their power to prevent or repress the crime." ${ }^{98}$ Therefore, while the policy is not necessarily criminal under international law, where a reasonable legal advisor would understand that the policy creates a permissive atmosphere for criminal conduct, the legal advisor should be held accountable for the actions that follow from that policy.

\section{CONCLUSION}

This analysis of culpability is narrowly tailored by the policy of deterrence. A person who leads others to commit a crime and the person who actually commits the crime share equal culpability in the commission of the crime. ${ }^{99}$ The Nuremberg Military Tribunal ("NMT") in the High Command Case succinctly described it this way: "It is self-evident that national policies are made by man. When men make a policy that is criminal under international law, they are criminally responsible for so doing. This is the logical and inescapable conclusion." 100 Furthermore, "[i]f the policy under which it is initiated is criminal in its intent and purpose it is so because the individuals at the policy-making level had a criminal intent and purpose in determining the policy." ${ }^{101}$ In addition, because the masterminds of the criminal violations are not involved with the physical action of committing the crime, failure to hold these masterminds accountable for their complicity would undermine the principle of deterrence. Since " $[\mathrm{t}]$ he acts prohibited are without deterrent effect unless they are punishable as crimes[,]" ${ }^{102}$ holding those creating the elaborate scheme has significant deterrent effect.

"We refuse to accept the notion that lawyers may do anything, including violating the law, to zealously advocate their clients' interests and then avoid criminal prosecution by claiming that they were 'just doing their job.' ${ }^{103}$ In many states in the United States a legal advisor is domestically responsible for his work product. His responsibility flows to his client and to the licensing

\footnotetext{
${ }^{98}$ Draft Code of P\&SM art 6, above note 3, [1996] 2 YB Int'l LComm'n at 25.

${ }^{99}$ Harris, above note 15 , at 503.

${ }^{100}$ High Command Case, above note 2, at 490.

${ }^{101}$ Id at 486.

${ }^{102}$ Hostage Case, above note 18, at 1240 .

${ }^{103}$ United States v Cueto, 151 F.3d 620, 634 (7th Cir 1998).
} 


\section{THE DENNING LAW JOURNAL}

authority that permits him to practice law. ${ }^{104}$ In addition, when the legal advisor is counseling the government on issues involving international law, the legal advisor has an obligation not only to the general welfare of the citizenry ${ }^{\mathbf{1 0 5}}$ and the specific government agency requesting counsel, ${ }^{106}$ but also to the international community.

Especially in this age of globalism, a legal advisor's responsibility necessarily extends to the international community. ${ }^{107}$ Because "international law is not the product of an international legislature," 108 the legal advisor's role is especially important. Therefore, when a legal advisor takes a direct role in an international crime, he must be held responsible for it. In addition, where the legal advisor takes a direct role in a policy that while technically legal, creates a permissive atmosphere for illegal conduct, the legal advisor must be responsible for creating safeguards to prevent the possibility of illegal conduct.

\footnotetext{
${ }^{104}$ In the United States, a lawyer is responsible for his advice to his client and may be sued in civil court under professional malpractice. See, e.g., Doe v Hughes, 838 P 2d 804 (Alaska 1992) (rendering the law firm guilty of professional malpractice because it breached the duty of care owed to the client). Generally, a lawyer may also be disciplined by the state's highest court for professional misconduct. The Model Rules of Professional Conduct state that
}

[i]t is professional misconduct for a lawyer to:

(a) violate or attempt to violate the Rules of Professional Conduct, knowingly assist or induce another to do so, or do so through the acts of another;

(b) commit a criminal act that reflects adversely on the lawyer's honesty, trustworthiness or fitness as a lawyer in other respects;

(c) engage in conduct involving dishonesty, fraud, deceit or misrepresentation;

(d) engage in conduct that is prejudicial to the administration of justice;

(e) state or imply an ability to influence improperly a government agency or official or to achieve results by means that violate the Rules of Professional Conduct or other law; or

(f) knowingly assist a judge or judicial officer in conduct that is a violation of applicable rules of judicial conduct or other law.

Model Rules of Prof'l Conduct R 8.4(a) (2004); see, eg, In re Carnesi, 784 N.Y.S.2d 892 (NY App Div 2004) (accepting attorney's resignation and ordering that the attorney be disbarred and his name stricken from the roll of attorneys).

105 See, e.g., United States v Cueto, 151 F.3d 620 (7th Cir. 1998) (affirming defendant lawyer's conviction for conspiracy to defraud the United States and obstruction of justice).

${ }^{106}$ Bilder \& Vagts, above note 11, at 693.

107 See generally Winston P. Nagan, Lawyers Roles, Identity, and Professional Responsibility in an Age of Globalism, 13 FLA J INT'L L131 (2001) (explaining the various roles of a legal advisor).

${ }^{108}$ Major War Criminals, above note 5, at 221. 
THE DENNING LAW JOURNAL 